\title{
Reconsidering the Heartland: A Review Essay
}

\author{
MARVIN BERGMAN
}

Remaking the Heartland: Middle America since the 1950s, by Robert Wuthnow. Princeton: Princeton University Press, 2011. xiii, 358 pp. Appendix (23 statistical tables), notes, bibliography, index. \$35.00 hardcover.

Red State Religion: Faith and Politics in America's Heartland, by Robert Wuthnow. Princeton: Princeton University Press, 2012. xii, 229 pp. Illustrations, notes, bibliography, index. $\$ 35.00$ hardcover.

OVER THE PAST FEW DECADES, many books and countless articles have appeared bemoaning the existing and declining state of the rural Midwest. ${ }^{1}$ Others have attacked a perceived unhealthy relationship between religion and politics in the region. ${ }^{2}$ In response, Robert Wuthnow, an acclaimed and prolific sociologist of American religion, has produced two significant books about his native Midwest. One counters the dominant narrative of the decline of the rural Midwest; the other provides a rare nuanced account of the relationship between religion and politics in a midwestern state.

1. An early, influential example is Osha Gray Davidson, Broken Heartland: The Rise of America's Rural Ghetto (1990; expanded edition, Iowa City, 1996). Other examples of just a few focusing on Iowa include Dale Maharidge, Denison, Iowa: Searching for the Soul of America through the Secrets of a Midwest Town (New York, 2005); Patrick J. Carr and Maria J. Kefalas, Hollowing out the Middle: The Rural Brain Drain and What it Means for America (Boston, 2009); Nick Reding, Methland: The Death and Life of an American Small Town (New York, 2009).

2. See especially Thomas Frank, What's the Matter with Kansas? How Conservatives Won the Heart of America (New York, 2004).

THE ANNALS OF IOWA 72 (Summer 2013). (C) The State Historical Society of Iowa, 2013. 
Remaking the Heartland can be read as an answer to the pervasive declension narrative. Its argument is simple but striking: "By the first decade of the twenty-first century, the Middle West was a more vibrant contributor to the national economy than it had been a half century earlier" (ix). For many readers, accustomed as they are to reading about how awful conditions are in the rural and Rust Belt Midwest, this claim will come as a surprise. We have, of course, heard the worst stereotypes of the declension narrative answered by midwestern apologists with vapid generalizations about midwestern character, as Iowans did in response to a controversial essay by journalist Stephen Bloom published just weeks before the 2012 Iowa caucuses. ${ }^{3}$ Wuthnow's approach is much more substantive. He does not deny that some places and some elements manifest decline, but, as he often says after stating a prevailing understanding, "it's more complicated than that." He then presents hard evidence to support his countervailing view. That approach tends to inspire trust.

Furthermore, I believe that residents of the places he writes about would recognize their places in his telling; I'm never sure about that when I read books that carry the declension narrative. Those residents, too, are agents in his stories rather than mere victims of larger historical forces. He writes, for example, "The farmer's son who leaves for college and the father who worries that his son may not return reflect the human drama taking place here in rural America. It is understandable that people

3. Stephen G. Bloom, "Observations from 20 Years of Iowa Life," The Atlantic, 12/9/2011, www.theatlantic.com/politics/archive/2011/12/observationsfrom-20-years-of-iowa-life/249401/, accessed 3/26/2013. The web site includes many, many responses. University of Iowa president Sally Mason's published response was typical. She wrote, "What defines Iowans are their deeds and actions and not some caricature. When I travel the state, what I see is a land that is rich not only because of its soil but because of how its people are grounded. Iowans are pragmatic and balanced, and they live within their means. This lifestyle, while not glitzy, is humble and true and can weather the most difficult of times. One's reputation and word are understood to be his or her most valued attributes. As a result, people cultivate a sense of fairness, cooperation, and humility." Sally Mason, "Stephen Bloom Does Not Speak for the University," The Atlantic, 12/15/2011, www.theatlantic.com/politics/ archive/2011/12/stephen-bloom-does-not-speak-for-the-university/250073/, accessed, 3/26/2013. Mason's response also appeared in newspapers across Iowa. 
mourn the departure of their children, but it is equally important to understand that they know this is the reality they face and have usually played a positive role in encouraging it. Populations decline not only because people are forced to leave but also because they choose to do so, and because those who stay behind are often better able to be productive and efficient as a result" (13).

People interested in the larger history of the region will also appreciate that, for a book ostensibly about the years "since the 1950s," a surprisingly high proportion is about the years before 1950, especially settlement patterns. Many of his explanations begin, perhaps unexpectedly for a sociologist, with a comment to the effect that to understand the given issue requires a look at the longer history.

In chapter one, Wuthnow establishes that life in the Midwest in the 1950s was not the idyllic rural life of nostalgia or contemporary stereotype. Housing conditions were harsh for a large minority of people, and mobility and transience were common in the 1950s as they had been earlier (especially in the 1930s) and would be again later.

Chapters two and three focus on images of the Midwest (both self-image and external), emphasizing how those images were shaped by understandings or distortions of the experiences of (1) the Wild West (as reflected especially in Wild West shows);

(2) homesteading (especially as in Laura Ingalls Wilder's Little House books), and (3) the Great Depression (Grapes of Wrath and The Wizard of $\mathrm{Oz}$ ). A theme that runs through these chapters - and, indeed, throughout the book - is that midwesterners survived through hard times not only because of characteristics commonly attributed to them (ingenuity, persistence, and selfreliance) but also because of (seldom acknowledged) government assistance. Depending on the reader's ideological bent, some may think that Wuthnow makes too much of this point; others will believe that the point could be stressed more explicitly and emphatically.

Readers of this journal will be interested to note that in his chapter on education (chap. 4), Wuthnow selected Vinton, Iowa, as representative of "the development of Middle Western education" (98), though nothing in the text or footnotes sug- 
gests how or why he did so. His attention to higher education as well as primary and secondary education is welcome. It is amazing to see how quickly attitudes toward higher education changed. For most of the region's history, few rural students went to college; by the late 1960s, even rural midwesterners acknowledged that most good students would pursue higher education. An inevitable theme of this chapter is the so-called brain drain from the Midwest. Wuthnow's analysis, which observes that Iowa, Nebraska, and the Dakotas suffer more from brain drain than Minnesota, Kansas, and Missouri, fails to note the role of larger urban areas in the latter states as a factor in the differing rates of brain drain.

Chapter five, on the decline of small communities, especially since 1980, offers a large array of statistics to support a mostly common-sense explanation for why some have declined and others have not. The smaller a town was, the more likely it was to face decline. It was also more likely to decline if it was not a county seat; if the number or value of farms in the county declined at a rate above the average for the region; and if there were more than two competing towns in the county or if the town was smaller than the average size for its county. And, of course, where there was an oil or military installation, towns grew, at least temporarily. "When none of these conditions was present, 96 percent of the towns grew, but when four or five were present, about two-thirds of the towns declined" (136). One counterintuitive finding: the Great Depression was not a major factor in community decline in the region. Wuthnow devotes only one paragraph (145) to the effects of location near an interstate highway, even though that impact is statistically more telling than some of the others discussed at greater length.

Chapter six focuses in on what is probably the most potent factor altering midwestern communities: the dramatic changes in agribusiness, especially meatpacking. Once again, Wuthnow is careful to set recent developments in a longer history. As he says, to understand the issues related to the recent history of meatpacking and new immigration "requires starting earlier than . . the 1980s." He then offers an account of the development of the county in which Garden City, Kansas, is located, beginning with its settlement patterns (174-81). The point of his 
account is to show that large-scale attempts at vertical integration of markets and their effects on local economic and social relations are nothing new in the region. Here, as elsewhere, it would have helped readers if he had made more explicit the connections he sees between the earlier history and the consequences of recent developments, but the attempt to set recent history in a longer historical context is nonetheless welcome. His account of the controversial changes in agribusiness and in the affected communities is more nuanced and balanced than most accounts of these changes. That will undoubtedly prove frustrating to readers who wish he had emphasized more clearly the costs of the changes (and perhaps equally frustrating to other readers for the opposite reason).

The chapter on edge cities (chap. 7), with its compilation of business histories, counters the assumption that these places are primarily bedroom communities for urban centers. "Together," he notes, "manufacturing and wholesale receipts were more than two and a half times larger than retail receipts in edge cities and exceeded total manufacturing and wholesale receipts in the region's core cities" (243). This chapter focuses primarily on the Kansas City and Minneapolis metropolitan areas, but its argument and development might be profitably applied as well to Des Moines and Omaha-Council Bluffs.

Throughout the book, Wuthnow employs a broad range of statistics to good effect. Unfortunately, his fascination with statistics diminishes the pleasure of the book as a reading experience. The book successfully, in my view, counters a number of assumptions and arguments about the Midwest, but it is unlikely to be widely read, not because it goes against the grain, but because all too often if reads like a compilation of statistics.

Some readers, too, may be perplexed by Wuthnow's idiosyncratic definition of the "Heartland." He excludes the states of the Old Northwest but does include Arkansas and Oklahoma. His home state of Kansas receives a disproportionate share of attention.

Kansas is even more explicitly the center of attention in Red State Religion: Faith and Politics in America's Heartland. In fact, the book could be profitably read as a survey history of Kansas politics, with side trips to discuss the history of religion in the state. 
Like most traditional political state history texts, Red State Religion is based on sources traditionally used by historians, especially newspapers, oral interviews, and county-by-county election statistics; and Wuthnow often employs and addresses the work of other historians. He does, however, make greater use of survey data than most historians do. Although focused almost exclusively on Kansas, the book deserves the attention of those interested in other states in the Midwest. Kansas developments traced to "Bleeding Kansas" are unique, but much of the rest of Kansas history shows parallels to Iowa, with Kansas being perhaps the only state that can claim to be even more reliably Republican than Iowa (although Iowa has, since the 1960s, become much more a two-party state).

To be sure, Kansas is a fine laboratory for such treatment. From John Brown yielding God's sword at the time of Bleeding Kansas, through Carry Nation's saloon-smashing campaign in the first decade of the twentieth century, to the Wichita abortion battles of the 1980s and later, Kansas has seemed particularly susceptible to excess in the relationship between religion and politics, and that is the image most often portrayed in discussions of the state. Wuthnow does not minimize those episodes. Yet for much of the state's history, he struggles to relate developments in the field of religion to the realm of politics. In fact, his sections on religion often read like sidebars to a traditional state political history. But that, in fact, reflects his stated thesis: "that the Republican Party and the centrist conservatism of the state's two dominant religions - Methodism and Catholicismactually deterred radical religious and political movements from gaining much ground during much of the state's history" (xii, articulated more fully on p. 209). It was, he argues, the emergence and rapid growth of new denominations-especially Southern Baptists - that set the stage for the activism of the Religious Right in recent years.

The focus on the centrist conservatism of the state's Methodists and Catholics means that Wuthnow tends to overlook what diversity does exist in Kansas. It would be interesting, for example, to read about how the culture of Topeka could spawn and nurture simultaneously at the turn of the twentieth century the likes of Charles Sheldon, author of the best-selling and 
widely influential book In His Steps (which spawned a "What Would Jesus Do?" fad that predates the more recent one by about a century); Charles Parham, often credited as one of the main founders of Pentecostalism; and Karl Menninger, founder of the Menninger Foundation and Menninger Clinic.

Wuthnow acknowledges that the story of religion should not be reduced to the way it relates to politics. "Religion was generally more significant in private life than it ever was in the political sphere. People cared about it because they believed their salvation was at stake. It mattered how their children were raised, which church they belonged to, and who they married. They were willing to accept some religious differences, but not others. Those differences influenced who they saw as their friends or foes, what they felt about social issues, and how they voted" (11). He cites a study of Oskaloosa, Kansas, in the 1950s that found that 75 percent of the town's residents were members of one of the town's churches, and that churches were intimately integrated into the town's overlapping social networks (198).

Readers of this journal will appreciate that Wuthnow recognizes that "understanding the public role of religion requires playing close attention to state and local politics." That is, one should not assume that the significance of a state being blue or red matters only in national politics. Religious groups, as he shows, are often more effective in "influencing state legislators and governors, and shaping the decisions of school boards and courts" (369).

Wuthnow periodically employs statistics from religious censuses to mark the evolving relative strength of various religious denominations in Kansas, but because he uses such statistics more sparingly than he does in Remaking the Heartland, Red State Religion is generally more readable. Both books deserve attention from those who care about the history and fate of the communities and states in the Midwest. 